University for Business and Technology in Kosovo

UBT Knowledge Center

UBT International Conference

2013 UBT International Conference

Nov 2nd, 9:40 AM - 9:50 AM

\title{
Analyses of Efficiency and Productivity in MFIs in Post Conflict Countries, using Best Practices and Methodologies
}

Ismet Pireva

University for Business and Technology, ismet_pir@hotmail.com

Edmond Hajrizi

University for Business and Technology, ehajrizi@ubt-uni.net

Follow this and additional works at: https://knowledgecenter.ubt-uni.net/conference

Part of the Business Commons

\section{Recommended Citation}

Pireva, Ismet and Hajrizi, Edmond, "Analyses of Efficiency and Productivity in MFIs in Post Conflict Countries, using Best Practices and Methodologies" (2013). UBT International Conference. 37. https://knowledgecenter.ubt-uni.net/conference/2013/all-events/37

This Event is brought to you for free and open access by the Publication and Journals at UBT Knowledge Center. It has been accepted for inclusion in UBT International Conference by an authorized administrator of UBT Knowledge Center. For more information, please contact knowledge.center@ubt-uni.net. 


\title{
Analyses of Efficiency and Productivity in MFIs in Post Conflict Countries, using Best Practices and Methodologies
}

\author{
Ismet PIREVA, Edmond Hajrizi \\ University for Business and Technology \\ ismet pir@hotmail.com
}

\begin{abstract}
Abs tract. This paperthes is analyses the performance of Microfinance Institutions of type NGO/NBFI for period from 2002 to 2011, in the five Post-Conflict countries in the Balkan Region, referring to financial and operational data published on credible websites and articles, opinions, and papers. Based on the conclusions deriving from the analyses done in this paper, but also comparing to conclusions and other different opinions given by different actors of the financial industry, subject of this thesis intends to identify the causes for deterioration of performance of Microfinance Institutions in post-conflict countries market, in the years of 2008 and on. While many factors that drives detorioration of performace of MFIs might be external and therefore not controlled, there are internal factors and controlled. This thesis treats internal factors - the controlled factors such as:

1) Time to reaction/flexibility/agility;

2) Cost Efficiency and productivity;

This paper conclusion is that the microfinance is a risky business that is highly affected by the external factors. In order to balance this risk and to survive the crises, MIFs needs to remain reactive, efficient and productive.
\end{abstract}

Key words: Microfinnce Institution, Efficency, Effectivnes, Best Practises

\section{Introduction}

Last updated data regarding MFI industry are showing that due to difficulties in micro financial market (difficulties with funding) and external environment as well (non-financial performance indicators), non-efficiency and no profit is noticed overall MFI s, mainly due to lack and not well defined cost structure, imbalance between operation costs and their portfolio; Therefore there is a need / MUST for practical approach to intelligent analyses for cost management with the main aim of improving efficiency and increasing profitability (balancing of operational cost vs existing portfolio) .

\section{Statement of the purpose and scope of the study}

The main purpose of this study is two folds:

- What are main factors for performance deterioration of the performance for MFI's under study for the selected countries?

- To test whether the falling down the efficiency/productivity, is an important factor for performance deterioration of MFI's under study?

The study only utilizes 6 indicators and makes the generalization for 5 countries under investigation.

\section{Literature review}

\subsection{Efficiency drivers in MFIs:}

Todd Farrington, a financial economist who has evaluated MFIs with Private Sector Initiatives/Micro Rate since June 1997, has evaluated the efficiency in Microfinance Institutions using Benchmark and 
Inefficient Models, has explained the efficiency driver and the impact of the efficiency in increase/deterioration of MFIs profitability.

Farrington's model of study used to treat factors that contribute to, and hinder, efficient microfinance, explains the following:

\section{Measuring Efficiency:}

- The Administrative Expense Ratio (administrative expenses as a percentage of average gross portfolio);

- The Number of Loans per Loan Officer (reflects the productivity of the field staff);

- The Ratio of Loan Officers to Total Staff (is a proxy for the institution's ability to allocate resources to its core business: lending)

\section{Efficiency Drivers:}

If these ratios are the measures of efficiency, what factors drive their change? For this purpose he has considered five important efficiency drivers:

- portfolio size,

- loan size,

- lending methodology,

- the source of funds, and

- the salary structure:

\section{Profitability of MFIs}

\section{Profitability measures:}

Any ordinary business is most concerned with its profitability, since if there is no basis for profit, or break even, the business will seize to exist. MFIs differ a bit, since subsidies and donations work as a kind of safety net for some institutions, so that other priorities come first. However, due to the rapid growth of the industry, profitability has become an important priority and a step in becoming sustainable, and it is therefore important to know different ways to measure profitability.

Profitability ratios are used to determine the company's bottom line and are important to company managers and owners alike. If a small business has outside investors who have put their own money into the company, the primary owner or manager has to show profitability to the equity investors. The ratios show a company's overall efficiency and performance and are in general divided into margin ratios and return ratios. Margin ratios represent the firm's ability to translate sales dollars into profits at various stages of measurement. Ratios that show returns represent the firm's ability to measure the overall efficiency of the firm in generating returns for its investors.

Return ratios are becoming increasingly important for MFIs due to their increasing use of investors. Return on assets and return on equity are the most important ratios.

i) The Return on Ass ets ratio (ROA), also called return on investment, is an important profitability ratio because it measures the efficiency with which the company is managing its investment in assets and using them to generate profit. It measures the amount of profit earned relative to the firm's level of investment in total assets. The return on assets ratio is related to the asset management category of financial ratios.

ii) The Return on Equity ratio (ROE) is perhaps the most important of all the financial ratios to investors in a company. This ratio measures the return on the money the investors have put into a company. This is the most important ratio that potential investors look at when deciding whether or not to invest in the company In general, the higher the percentage, the better, as it shows that the company is doing a good job using the investors' money. Sarah Guntz in Research Paper with 
title "Sustainability and profitability of microfinance institutions", explains how It is widely known that providing loans to micro-entrepreneurs has a relatively attractive potential to generate profits and growth. In some areas, like Asia, Africa and Latin America the profitability of MFIs is already squeezed by greater competition in the industry (Lascelles, 2008). She also explains how and what kind of costs, revenues and interest rates MFIs generate

\section{Methodology}

As it is indicated before, Microfinance Institutions (MFI s) are known for their dual orientation; however they need to remain at least self-sustainable, in order to continue their mission.

MFI Sector has had a good progress in Balkans during last decade, but serious problems have appeared in 2010, because of the following indicators:

- Financing structure;

- Fast and not under control growth;

- Efficiency;

- Expense;

- Profitability; and

- $\quad$ Risk indicators (unsound credit risk);

The following Hypothesis has been set to test:

1) Was it a weak reaction against external changes, an important factor for performance deterioration?

2) Was it a falling down the efficiency/productivity, an important factor for performance deterioration?

Todd Farrington Model: Model of (In) Efficiency has been utilized using the following indicators:

\section{MFIs Characteristics:}

- Total Assets

- Equity

- Total Offices

- $\quad$ Personnel (Total number of staff members)

\section{Overall Financial Performance/ Profitability Ratios:}

- Return on Assets (ROA) ratio

- Return on Equity (ROE) ratio

\section{Expense Indicators}

- Operating Expenses / Average Asset Ratio

- Provision for Loan Impairment / Assets Ratio

\section{Efficiency Indicators}

- Cost per Loan (CPL)

- Cost per Borrower ratio (CPB)

\section{Outreach Indicators}

- Number of active borrowers

- Average Loan Size 


\section{Productivity}

- Borrowers per Staff Member ratio

- Loans per Staff Member

- Borrowers per Loan Officer

- Loans per Loan Officer

- Personnel Allocation Ratio

Mix data taken for Mix Market website for MFI s of five countries in Post-Conflict Countries in Balkan for period 2002- 2011 (attached).

\section{Analyses of findings}

\section{Overall Financial Performance:}

Return of Assets (ROA) and Return on Equity (ROE) as usual indicators used to measure financial performance on an institution over prior period of time, shows the following results for MFIs under study, for period 10 years, from 2002 to 2011:

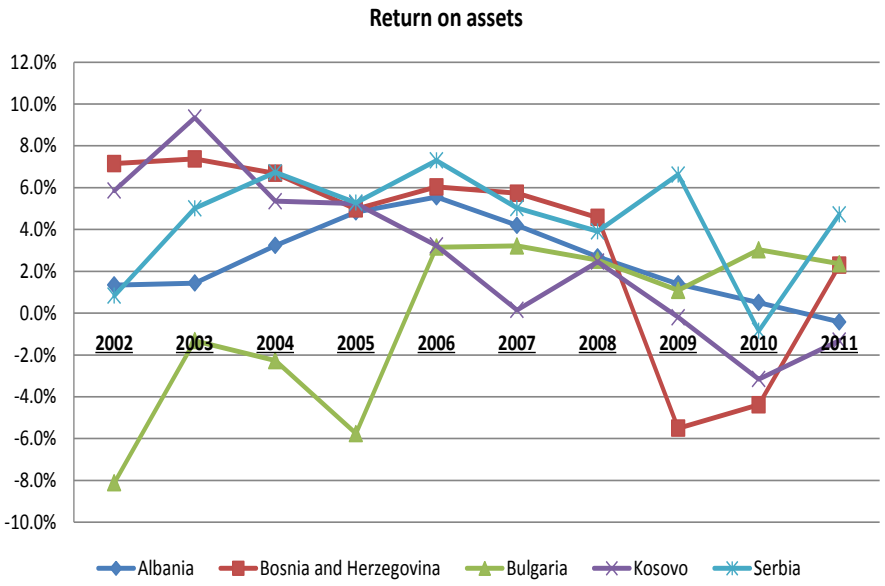

Fig. 1: Return of Assets Ratio for MFIs under study (2002 - 2011)

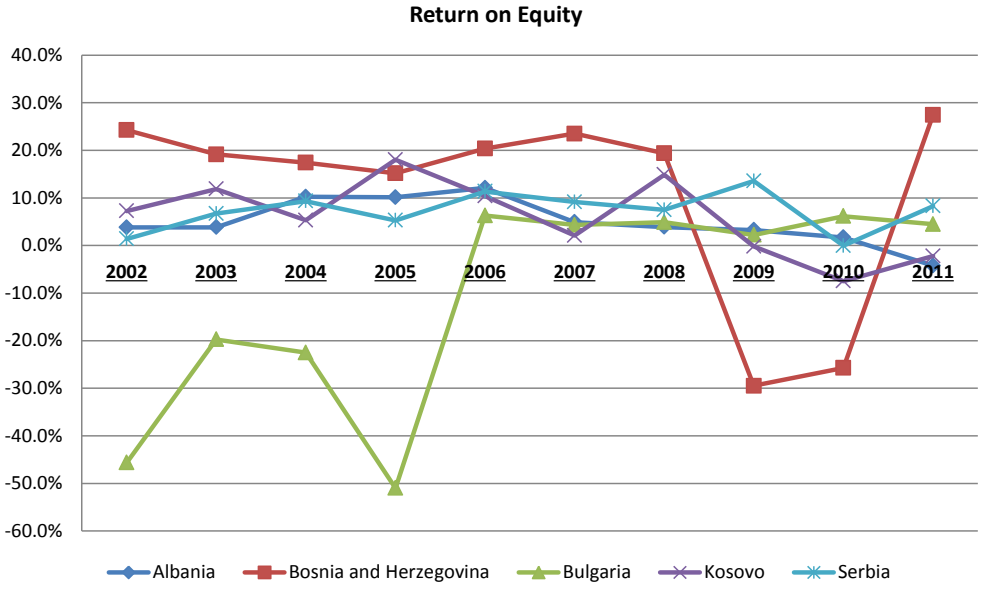

Fig 2: Return of Equity Ratio for MFIs under study (2002 - 2011) 


\section{Summary, Conclusion and Point of Departure}

In this paper Todd Farrington Model: Model of (In) Efficiency of MFIs and other different indicators, such as: Overall Financial performance indicators, Expense ratios, Efficiency and Productivity ratios, outreach indicators, MFIs characteristics, and other different indicators and best practices are used to analyze the efficiency and productivity in MFIs in Post Conflict countries.

According to analyzes and findings, utilizing Todd Farrington's model for evaluation of the efficiency in Microfinance Institutions, shows usefulness of the usage of the efficiency ratios, in further investigation of the impact of the efficiency, in increase/deterioration of MFIs profitability. As a conclusion when utilizing Farrington's model for analyzing efficiency in MFIs of five countries under study, we conclude that portfolio quality was a key factor in reducing administrative and provisioning expense, yielding increase of profitability. However when other efficiency drivers (portfolio s ize and loan size) and indicators (cost per loan ratio, and cost per borrower ratio) were considered during analyzes, we came to a conclusion that the efficiency drivers such as: portfolio size and loan size are of big impact in the deterioration of financial performance of the MFIs under study. To interpret this we use the case with MFIs in Bosnia and Herzegovina in 2009, where deterioration of portfolio quality, uncontrolled growth and effect of double funding (wrong lending methodology) have deteriorat ed overall financial performance of MFIS in this country.

Utilizing other financial indicators, such as: return on assets (ROA) and return on equity (ROE) for analyzing profitability of MIFs under this study, we noticed deterioration of these ratios occurring in 2009 and 2010, due to high impairment losses starting in 2008 and to be followed by 2009 and 2010. Worsen deterioration is noticed in MFIs Bosnia and Herzegovina with deterioration of ROA ratio from $4.6 \%$ in 2008 to $-5.5 \%$ in 2009 , and similar with Kosovo MFIs, with deterioration this ratio for $2.5 \%$ in 2008 to $-0.2 \%$ in 2009 , and deteriorating further to $-3.2 \%$ in 2010 , due to higher impairment loses in 2010, fast and not under control growth.

\section{References}

1. Farrington, T. (2000): Efficiency in Microfinance Institutions - Todd Farrington, http://www.wtrctmed.org/resources/Efficiency\%20in\%20MFIs.pdf,

2. Nørgaard Jørgensen A. (2011): The profitability of microfinance institutions and the connection to the yield on the gross portfolio - An empirical analysis, http://studenttheses.cbs.dk/bitstream/handle/10417/2914/anne noergaard joergensen.pdf?sequenc $\underline{\mathrm{e}=1}$

3. Guntz S. (2011): Sustainability and profitability of microfinance institutions, Research Paper 4/2011,

nuernberg.de/fileadmin/Fachbereiche/bw/studienschwerpunkte/international bus iness/Master/CA $\underline{\text { IFD/ResearchPapers/SustainabilityAndProfitabilityOfMicrofinanceInstitutions Guntz.pdf }}$ 